\title{
АКТУАЛЬНА ТЕМА
}

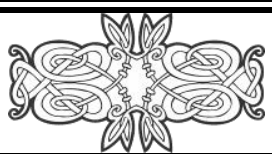

\section{ACTUAL THEME}

\author{
УДК 657.6:334 \\ JEL Classification M 420
}

\author{
Пушкар Михайло \\ д.е.н., професор, \\ кафедра аудиту, ревізії та аналізу \\ Тернопільський національний економічний університет \\ Тернопіль, Україна \\ E-mail: mspushkar@gmail.com
}

\section{НАУКОВИЙ АПАРАТ ДЛЯ РОЗРОБКИ ТЕОРІЇ КОНТРОЛЮ}

\section{Анотація}

Bcmyn. Сучасний стан контролю не можна назвати таким, що впливає на практичну організацію контролю на макро і мікро рівнях управління економікою внаслідок суттєвого відставання теорії науки від практичних потреб. Відсутність розвинутої теорії породжує хаос контрольної діяльності в державі і деструктивні процеси в економічних сферах країни і бізнесу. Слабкість контролю провокує корупцію та безвідповідальність персоналу за наслідки прийнятих рішень.

Методи досліджень проблем розробки сучасної теорії контролю грунтуються на загальних, економічних та спеціальних засобах пізнання тенденцій і закономірностей розвитку наукознавства, фрілософії пізнання, історії, соціології, методології, досягнень різних наук, які можна запозичити для інтелектуалізації контрольного процесу. Пізнання неможливе без діалектичного способу мислення, що вимагає врахування специфіки роботи контрольних працівників та її розкриття в теорії контролю.

Результати досліджень проблем теорії контрольних наук свідчать про надзвичайно низький інтелектуальний рівень наукового узагальнення контрольного процесу, який призваний підняти практику на вищий рівень. Недосконала система обліку дає надто мало інформації для контролю, що робить його неефрективним. Контроль задовольняється тим набором економічних показників, які генерує «бухгалтерський» облік, і тому констатує лище правильність виконаної роботи обліковим апаратом замість ього, щоб вивчати есективність процесів господарювання й управління.

Перспективи розвитку контролю автор вбачає у створенні такої теорії, яка грунтується на принципах теорії пізнання, що передбачає абсолютно нові підходи до світосприйняття такої категорії як контроль, структура його системи, функцій, завдань, мети, методології та інших елементів. Без наукової концепиії підготовки кадрів для контрольних служб, формування їх світобачення та створення ефективної системи контролю досягти належного рівня якості виконання контрольних функцій досить проблематично.

Ключові слова: контроль, система, облік, види обліку, наука, теорія пізнання, управління, перспективи розвитку.

\section{Вступ.}

Контроль настільки складне поняття з точки зору науки, що його зміст до нашого часу так і не визначено на більш - менш задовільному рівні, хоча на рівні буденного мислення ним, як явищем для повсякденного вжитку, користуються усі підприємства і всі люди без виключення на буденному рівні мислення. Неможливо уявити будь - яку сферу людської діяльності поза процесом контролю, особливо фахівців, що професійно займається управлінською справою. 
Менеджери здійснюють свою роботу на основі загального циклу управління, який формально складається з взаємозалежних блоків - планування, організації, мотивації і контролю. Якщо перші три блоки загального циклу управління детально описані в теорії менеджменту та успішно застосовуються у практичній діяльності, то контроль висвітлено досить фрагментарно і поверхово. Це виглядає дивним, зважаючи на те, що контроль притаманний людям ще 3 доцивілізаційного періоду розвитку історії - періоду дикості та варварства. Виникає питання, чому за всю історію людства контроль, як складова менеджменту, не має розвинутої теорії або концепції?

Справа у тому, що пізнавальна діяльність і формування наукових знань може відбуватися в різних формах:

- асиміляції наявної інформації про предмет, коли зростає обсяг знань без суттєвого перегляду базових емпіричних положень, які носять донауковий характер;

- доповнення вихідних теорій, концепцій, наукових узагальнень новими елементами як результат досліджень та глибшого пізнання законів реального світу.

Форма доповнення пізнавальної діяльності новими елементами носить назву зміни «парадигми», того взірця, шаблону, кліше, який характеризує науку в моменти ії революції, а творцями революції стають науковці внаслідок творчих можливостей їх пізнавальної діяльності. Такий підхід повинен бути засобом конструктивного творення структури теорії контролю.

\section{Аналіз останніх досліджень і публікацій.}

Аналіз публікацій і досліджень свідчить про те, що коло авторів з теорії досить обмежене, хоча $з$ методики проведення контролю таких публікацій величезна кількість. Перша публікація присвячена теорії контролю з'явилися в1974 р., автором якої був Кочерін Є. А. [1], а пізніше опубліковані роботи Відяпіна В.Г. [2], Білухи М. Т. [3], Шевчука В. О. [4], Ярошенка С. П. [5], Виговська Н. Г. [6], Редченка К. І. [7], Пушкар М. С. [8; 19], та значна кількість інших авторів, які розкривали окремі аспекти теорії. Аналіз проблем теорії науки та їх вирішення, творче відношення до проектно - конструктивного пізнання може дати новий матеріал для розвитку науки і практики. На жаль, у багатьох публікаціях наводиться проста констатація відомої інформації щодо окремих часткових питань контрольного процесу і до цього часу контроль залишається в науковому сенсі аморфним знанням, що коментує дані недосконалої системи обліку на основі застосування окремих контрольних процедур виконавців, засвоєних на досвіді без належного теоретичного узагальнення.

\section{Мета.}

Мета дослідження покликана привернути увагу науковців до незадовільного стану контролю та організувати дискусію щодо створення розвинутої теорії, здатної підняти рівень контрольної діяльності в країні на якісно новий рівень.

\section{Результати.}

Науковець повинен виступати активною силою по відношенню до об'єкта дослідження контролю, розкриваючи його сутність, а об'єкт розглядати як постійно змінюваний елемент пізнання. Діалектика вчить, що зміни відбуваються не лише в арсеналі пізнавальних засобів науковця, а й в об'єкті дослідження, а тому в науці потрібно бачити взаємозв'язок і взаємодію суб'єкта з об'єктом враховувати зміни економічного середовища та фактори, що їх обумовлюють. Видозміни в об'єктах вимагають від суб'єкта уточнення вихідних принципів, норм, засобів, програм дослідження контрольної діяльності. Сучасна економічна наука досить широко використовує системний метод дослідження. У філософсььому сенсі будь-які економічні системи штучно створюються людьми для вирішення практичних завдань.

Спрощене розуміння контрольної діяльності науковцями, які досліджують проблеми контролю, зводиться до шаблону, коли їх публікації ґрунтуються, у більшості випадків, на окремих емпіричних прикладах, проте пасивне споглядання того, як виконує свою роботу практик і 
описування дій «ревізора», виключає критичне мислення та узагальнення на теоретичному рівні.

Дослідження проблем теорії контролю потрібно здійснювати на основі теорії пізнання і системного підходу. Загальна теорія систем нараховує вісім рівнів, кожний з яких характеризує стан і поведінку систем в таких аспектах [9, с. 50-51]:

- лінгвістичному (символьному, за допомогою мови та понять науки);

- теоретико - множинному (виділення у системі окремих підсистем);

- абстрактно - логічному (виділення систем і підсистем та їх властивостей з допомогою інтелекту людини);

- топологічному (класифрікація систем та вивчення особливостей їх функціонування);

- логіко - математичному (математичне вираження поведінки систем);

- теоретико - інформаційному (властивості систем та підсистем генерувати різноманітну інформацію);

- динамічному (зміна структури, функцій, елементів систем);

- евристичному (відкриття властивостей систем на підсвідомому рівні на основі минулого досвіду).

Теоретичним базисом систем виступає кібернетика (грец. kibernetike - мистецтво управління) - наука про найбільш загальні закономірності отримання даних та їх трансформування в інформацію, а також управління в системах. Сутність кібернетики полягає в обміні інформацією між системами, якими управляють і системами, які управляють. Обмін відбувається за допомогою каналу зворотного зв'язку, коли інформація надходить в систему управління.. для оцінки ситуацій та регулювання діяльності виробничих систем. Кібернетика опирається на системні дослідження, в яких центральним поняттям є об'єкт, взаємодія і середовище:

- об'єкт - стійке у часі й обмежене у просторі утворення, що знаходиться у відносинах 3 іншими об'єктами, як єдине ціле чи елемент системи; взаємодія - концептуально безперервний процес взаємообумовлених зв'язків між елементами системи та середовища із системою, що свідчить про трансформацію параметрів об'єкта і середовища внаслідок руху та змін матеріального світу;

- середовище - множина об'єктів, зв'язків, відношень між ними, які впливають на систему та її елементи.

Ці елементи створюють систему контролю, метою якої $є$ відстеження параметрів роботи підприємства у відповідності до його стратегічної мети та виявлення факторів впливу середовища і системи управління на отриманий фрактичний результат. Система використовують як кібернетичну модель поведінки об'єкта дослідження, яка впливає на такі важливі напрями науки, як системотехніка, аналіз систем і системні моделі в економічних науках, у тому числі й контролі. Без застосування кібернетичного підходу неможливо досліджувати процес становлення і розвитку контролю, як науки, оскільки теорія також $є$ системою, яка призначена для організації практичних дій при відстеженні тих процесів, які відбуваються у фінансовій та господарській діяльності підприємства.

Однією із складових науки є методологія пізнання, яку представники контрольних наук часто трактують в досить спрощеному варіанті, коли зводять цю складну філософську категорію до набору окремих методів. Таке розуміння методології $€$ метафізичним, в ньому відсутній науковий підхід до теорії, що генетично пов'язано з емпіричним етапом розвитку науки. Проте, емпіричний рівень досліджень показує зв'язок з практичною діяльністю, а теоретичний рівень - з теорією пізнання, зокрема з гносеологією, сутність якої полягає в тому, що вона тотожна поняттю теорії, яка вивчає взаємовідношення суб'єкта і об'єкта у процесі пізнавальної діяльності, відношення знання до дійсності, критерії достовірності та істинності знань, можливості пізнання світу.

До проблематики гносеології (теорії пізнання) відносять [10]:

- співвідношення змісту і форми;

- співвідношення свідомості та матерії; 
- співвідношення матеріального та ідеального;

- співвідношення суттєвого і логічного;

- проблема відображення речей, явищ і процесів;

- критерії достовірності знань;

- форми пізнання;

- інші питання функціонування пізнавального апарату людини 3 точки зору загальнофрілософоських підходів.

Процес пізнання людини ґрунтується на законах суспільного розвитку і обумовлений практикою процесу відображення та відтворення в людському мисленні реальної дійсності. Набуті знання використовують у практичній діяльності, тому справедливим $є$ твердження, що критерієм істини виступає практика. Звичайно, коли говорять про істину, то акцент роблять на слові «практика», що гіпертрофує її роль у пізнанні. Сама по собі практика відображає лише результат використання набутих раніше знань і не може слугувати базою для отримання нових знань. Враховуючи потенційні можливості мислення людини наука здатна за допомогою понять, суджень, гіпотез, концепцій, теорій, зміни парадигм активно впливати на освоєння світу з постійно зростаючою глибиною. Мозок людини розвивається не лише, як фізіологічний апарат мислення, а й під впливом суспільного розвитку та наукового освоєння оточуючого світу [11; 12].

Зрозуміло, що наука не може розвиватися без дієвого апарату пізнання, який постійно ускладнюється, що вимагає від науковців його освоєння та використання у дослідженнях. Проте, у багатьох випадках публікації авторів з теорії контролю не проясняють сутності явищ і процесів контрольної діяльності на підприємці через термінологічну плутанину, коли в одні і ті ж поняття науки вкладають різний смисл. У зв'язку з цим важливою проблемою теорії стає створення термінологічної системи наукового знання. 3 цієї проблеми опублікована стаття В.Рача, О. Россошанської та О. Медведєвої у журналі «Науковий світ» $[13$, с. 13-16], в якій наведено сутнісно - явищну пірамідальну модель термінологічної системи та виділено три рівні організації наукового знання.

Перший рівень методологічний - розкриває контроль у двох аспектах:

- сутністно - явищному, що пізнається одночасно мисленням (пізнається сутність науки про контроль) та органами відчуття людини (пізнається явище контролю) та характеризує:

$\checkmark$ перспективу розвитку науки (альтернативи майбутньої парадигми);

$\checkmark$ існуючу парадигму (стійке бачення науки як системи філософських світоглядних положень досліджуваного явища, що визначає вибір проблем, напрямів наукового пошуку, методів та інструментів пізнання для розв'язання проблем);

$\checkmark$ теорію (систему теоретичних положень, які у межах парадигми формалізують сутнісні (мисленні) закономірності функціонування і змін в об'єктах реальної дійсності);

$\checkmark$ методологію (у межах теорії розкриває філософські та світоглядні положення на основі принципів, методів та інструментарію пізнавальної, освітньої й прагматичної діяльності шляхом узагальнення фактів, тенденцій, закономірностей і законів, що описують явища об'єктивного світу);

- чисто сутнісному, що грунтується на мисленнєвих конструкціях науки:

$\checkmark$ розробці термінологічного словника науки про контроль;

$\checkmark$ уточнення загальноприйнятих і нових понять і дефініцій науки про контроль; використовуваних переважною більшістю наукового співтовариства на сучасному етапі розвитку економічної теорії;

$\checkmark$ формулюванні дефініцій, аксіом, теорем, гіпотез про явища і процеси контрольної діяльності, як системи для відстеження поведінки підприємства і досягнення мети управління;

$\checkmark$ розробці концепції, яка заміщає теорію науки до того часу, поки не буде сформована розвинута теорія.

Другий рівень - методовизначальний, який деталізує положення контролю першого рівня пізнання через використання різних методів пізнання (використання емпіричних методів, правил, 
усунення протиріч тощо), які характеризують контроль, як явище та формулювання тенденцій, закономірностей, умовиводів при розгляді контролю, як сутності.

Третій рівень методичний - описує контроль, як явище, з використання класифікацій та моделей функціонування, та, як сутність, що розкриває зв'язки, відношення між елементами науки, взаємодію з іншими системами тощо. Отже, критерії науковості потрібно наводити не в хаотичному стані елементів науки, що притаманно сучасним працям з теорії контролю а в їх упорядкуванні та взаємозв'язках.

Явище характеризує зовнішні ознаки контролю, які можна визначити на емпіричному (донауковому) рівні за допомогою органів відчуття, тому в теорії контролю використовують таку термінологію, що розкриває зміст перспектив розвитку, парадигми, методології, теорії, методів, правил, протиріч, моделей, класифрікацій тощо, а сутність - глибинні характеристики процесу пізнання, що ґрунтуються на мисленнєвому рівні узагальнення змісту контролю, основ науки, єдності властивостей і відношень між термінами, поняттями, дефініціями, аксіомами, теоремами, гіпотезами, концепціями, законами, закономірностями, зв'язками та відношеннями між елементами знання. Такий підхід до наукового пошуку досить раціональний, оскільки полегшує взаєморозуміння між науковцями різних спеціальностей, та сприяє взаємозв'язкам між окремими науками та їх взаємозбагаченню.

Мислення людини здійснюється в різних формах, які відображаються у теорії пізнання за допомогою таких процесів як:

- відчуття через органи людини безпосередньо (зір, слух, запах, смак, дотик);

- сприйняття (вплив реального світу на органи відчуття);

та ін.);

- вимірювання та оцінювання фактів (визначення характеристик - довжини, маси, обсягу

- уява (створення цілісного образу предмета через органи відчуття);

- вивчення факторів впливу на контроль (елементи дійсності - події, дані, явища, процеси в їх розвитку, взаємодії, переходах, відношеннях, вимірах, перетвореннях тощо);

- спостереження за фактами (система моніторингу, обліку, контролю, ревізії, аудиту та ін.);

- фріксування змін (наслідок руху і взаємодії між об'єктами пізнання, порушення стійкості, перехід кількості в нову якість тощо).

Пізнання спрямовується мисленням людини на практичне перетворення природи і суспільства, тому практична діяльність та пізнання розвиваються як два взаємообумовлені і взаємодоповнюючі моменти освоєння світу. Хоча відчуття людини й відіграють роль первинної ланки пізнання речей, явищ, процесів, але вони знаходяться на рівні досвіду, що дозволяє пізнати об'єкти реальності, як явище, що дає безпосередню інформацію про розмір, колір, масу, геометрію, твердість та інші характеристики.

Проте, такої інформації недостатньо для орієнтації у реальному світі, тому процес пізнання поглиблюється за допомогою мислення людини, яке дозволяє розкрити сутність, дати уяву про те, що являють самі по собі ті чи інші речі, явища і процеси, в чому їх відмінність від інших подібних об'єктів, які зміни в їх характеристиках відбуваються за різних обставин, як вони відносяться до нашої свідомості і мислення, як їх існування залежить від сутності та інші глибинні питання буття. Сутність пізнають через абстрактні поняття на основі свідомості та мислення, яке здатне створювати теорії починаючи з чуттєвого і закінчуючи раціональним рівнем пізнання з фіксуванням етапів його розвитку.

Процес пізнання переходить від зовнішньої констатації та описування явища до його пояснення (розкриття причин і основ), що становить сутність спостережуваних фрактів. Сутність може бути розкрита тоді, коли стають відомими причини виникнення і розвитку контролю, створена його аналогова модель функціонування та визначена мета системи, зрозуміла практична користь (інформація, що надходить у систему та реакція на неї з боку користувачів). Контроль, як явище, означає пізнання його зовнішніх ознак на рівні окремого підприємства (макрорівні), а як сутність - 
пізнання абстрактної внутрішньої конструкції контролю, як складової системи управління, та її елементів, взаємозв'язків, алгоритмів на макрорівні [14, с. 252].

Система передбачає також наявність суб'єкта, який організовує систематичне спостереження за поведінкою елементів системи у їі функціонуванні й розвитку та підтриманні робочого стану з метою досягнення тієї мети, яку визначено для неї.

Будь-яка система для свого існування вимагає певних зовнішніх умов, що робить ії відкритою, i, в той же час, стійкою, оскільки її розвиток спрямовується закладеною в ній програмою самозбереження. Чим ширша така програма й чим вона рухливіша, тим більше у неї можливостей відшукувати необхідні умови для існування і відтворення зовнішніх умов. Якщо коло умов для самозбереження і відтворення системи широке і різноманітне, то вихідна програма створює лише передумови подальшої орієнтованої діяльності. Вихідна програма функціонування системи дає лише відправні контури, загальні передумови поведінки, в межах яких можливе вирішення таких завдань, які виникають на основі створення образу наявної ситуації щодо ідеального плану дій. Отже, вихідна лінія прогресу щодо форм активності науковця полягає у зростанні можливостей поведінки (мова йде про інтелектуальну свободу та розширення об'єктів дослідження), а не обмеження набором жорстко заданих автоматично виконуваних алгоритмів.

Розробка теорії вимагає розширення поля досліджень об'єктів у часі й просторі, використання існуючих і потенційно можливих форм і методів контролю, в тому числі запозичених з інших наук, визначення більшого числа факторів впливу на діяльність підприємства, посилення інтелектуального рівня контрольної системи.

3 історичних джерел розвитку будь-яких наук відомо, що в основі їх змісту і структури було покладено потреби практики і лише через певний період, нерідко досить тривалий, формувалася теорія, яка осмислювала процеси формування знань та їх застосування на практиці. Наука повинна висвітлювати шлях для практики і зв своєю сутністю виробляти і прирощувати знання .

Аналіз рівня знань спеціалістів у галузі контролю, судячи з навчальної та наукової літератури, свідчить про його низький інтелектуальний і педагогічний потенціал, що можна пояснити такими причинами [8, с. 122-124]:

- прив'язкою контролю лише до однієї з підсистем облікової системи, а саме до фінансового обліку, коли до цього часу фінансовий контроль, майже виключно був зосереджений на підтвердженні тих чи інших фактів на рахунках обліку з точки зору їх арифметичної, логічної та правової основи відображення, що, в принципі, є хибним уявленням про функціонування як системи обліку, так і системи контролю. Облікова і контрольна системи різні за метою, концепцією, методами, інструментарієм досліджень та призначенням цих наукових напрямів економічної науки;

- відірваністю від потреб менеджменту, який здійснює загальний цикл управління, в тому числі й контроль, а тому облік повинен підпорядковуватися менеджменту підприємства, виконуючи сервісну функцію з підготовки необхідної для нього інформації. Облік у системі менеджменту виконує спеціалізовану сервісну функцію, яка полягає в тому, що він на основі принципу зворотного зв'язку дає інформацію про фактичний стан господарської діяльності для порівняння його з прогнозованим та здійснення коригування діяльності у випадку відхилень від передбачуваного стану об'єктів планування обліку працівниками системи управління. Облік виконує роль каналу зворотного зв'язку за допомогою відображення у символьній (знаковій) формі повідомлень про рух ресурсів, протікання процесів господарської діяльності, використання капіталу, формування фінансових результатів, стану взаємозв'язків підприємства з іншими підприємствами, отримання розгорнутої інформації про життєдіяльність, рівень ділової активності підприємства тощо;

- зміст контрольної діяльності визначається більше формою, процедурами й алгоритмами ніж структурою та складністю об'єктів перевірки, які вимагають нових, нетрадиційних методів збору й обробки даних та отримання інформації, зокрема, економічно-математичних і статистичних методів аналізу з метою виявлення закономірностей поведінки тих чи інших об'єктів, явищ і процесів підприємства; 
- контроль часто розуміють як засіб покарання перетворюючи його в самоціль, в той час, коли він повинен виступати частиною системи регулювання господарської діяльності (виявлення відхилень від установлених правил, принципів і застосування превентивних заходів з попередження неефективної діяльності персоналу);

- в цілому низьким рівнем професійної підготовки персоналу контрольних органів, які недостатньо обізнані з досягненнями в галузі методології пізнання, сучасними методами контролю і знаннями основ менеджменту, що породжує обмеженість та стереотипи проведення контрольних процедур, які не враховують специфіки об'єктів перевірки;

- недостатнім розвитком навчальної й методичної бази для підвищення кваліфікації фахівців з контролю (обмаль наукової літератури з контролю - монографій, статей у наукових журналах, недостатньо конференцій з наукової тематики, відсутність спеціалізованого журналу $з$ контрольних наук, недостатня мережа навчальних закладів з підготовки та підвищення кваліфікації кадрів);

- слабким взаємозв'язком контролю з іншими науками (плануванням, менеджментом, маркетингом, аналізом, математикою, прогнозуванням, психологією, інформаційною наукою тощо).

Контроль $є$ вродженою функцією людини, яку пов'язують з свідомістю і здатністю мислити, оцінювати ситуації та пристосовуватися до змін оточуючого середовища. Для орієнтації у реальному світі необхідно постійно отримувати через органи відчуття сигнали від об'єктів (речей, явищ і процесів) та за допомогою аналізу їх поведінки у просторово -часовому вимірі можна робити висновки про властивості, тенденції, причино - наслідкові зв'язки та коригувати дії людей у відповідності до отриманої інфрормації.

Контроль господарської діяльності передбачає організацію за певним планом спостереження на регулярній основі певного набору показників економічної та фінансової діяльності, фіксування відхилень фактичних значень показників від бажаного їх стану, виявлення причино - наслідкових змін, застосування активних дій щодо усунення негативних та закріплення позитивних фракторів впливу на результати роботи, коригування діяльності персоналу менеджерами підприємства.

Контроль спрямовують не стільки на оцінку дій підлеглих менеджерами щодо порушення регламентів виконання робіт чи нормативних вимог до них та покарання винних, скільки на вияснення впливу на діяльність окремих виконавців та структурних підрозділів підприємства глибинних, суттєвих фракторів об'єктивного характеру.

До контролю за діями персоналу ставлять такі вимоги [15, с. 383]:

- здійснювати оцінку діяльності персоналу на основі контрольних показників;

- враховувати індивідуальні і психологічні особливості працівників;

- дотриматись суб'єктами управління законності, встановлених регламентів і правил роботи;

- надавати вичерпну інформацію тим, кого перевіряють;

- досягти дієвості контролю, що передбачає не лише з'ясування стану об'єкта перевірки, а й допомогу підлеглим; підлеглих;

- враховувати принцип зворотного зв'язку, що передбачає отримання інформації від

- врахувати потреби підлеглих та стимулювати їх позитивну мотивацію до праці;

- здійснювати безперервний і регулярний контроль;

- зосереджувати увагу не лише на минулому, а й на майбутньому стані бізнесу;

- організувати самоконтроль суб'єктів перевірки (контроль емоцій, етикет, культура спілкування з підлеглими);

- д допускати правомірний ризик щодо виконання роботи підлеглиит у складних ситуаціях;

- інші фактори (освіта контролюючого персоналу, досвід роботи, креативність, ерудиція, знання теорії контролю тощо). 
Дотримання вказаних вимог до контролю дозволяє досягати бажаного рівня якості роботи контрольних працівників, але, як свідчить практика, рівень якості працівників контрольних служб поки що не задовольняє систему управління.

Зацикленість авторів навчальної літератури на стереотипних питаннях класифікації об'єктів, суб'єктів, видів контролю та методів перевірки збіднює проблематику контролю, що обумовлює відставання не тільки від сучасного рівня науки, а й від досягнень тридцятирічної давності, коли досвід контрольної діяльності було узагальнено й систематизовано в книзі «Енциклопедія сучасного управління» [16, с. 148], проте ці ідеї в повній мірі не знайшли втілення в життя до цього часу.

У практичній діяльності контрольну функцію доцільно здійснювати не за єдиною загальною абстрактною методологією, яку часто декларують науковці замість теорії, як інтелектуальної системи, а залежно від ієрархії управління починаючи з нижчого в напрямі до середнього і вищого рівнів менеджменту.

Нижчий рівень управління пов'язують з відстеженням менеджерами технологічних операцій за стадіями кругообігу капіталу - постачання ресурсів (відстежують логістичні, трансакційні, інформаційні та інші операції в розрізі матеріально відповідальних осіб та структурних підрозділів підприємства), виробництво продукції (аналіз витрат в різних ракурсах - за елементами, статтями, центрами витрат, сфрерами відповідальності, змінами, бригадами - за нормами, відхиленнями від норм та змінами норм витрат ресурсів та нормативів часу, витрат на устаткування, організацію та управління, якість продукції тощо), збут (логістичні витрати, ціноутворення, просування продукції на ринок, маркетингові та збутові витрати за нормами, відхиленнями від норм і зміною норм).

Менеджери середнього рівня управління відстежують показники фінансової діяльності для чого використовують підготовлені економічними службами зведені місячні та квартальні звіти підприємства і його структурних підрозділів про роботу. Контроль роботи відповідальних за результат діяльності осіб вимагає детального аналізу використання фракторів виробництва, зв'язків з постачальниками і покупцями, кон'юктури ринку, ціноутворення, тенденцій у попиті на продукцію тощо.

Вищий рівень управління пов'язують із здійсненням директоратом підприємства контролю 3 питань стратегії розвитку підприємства, окремих зон господарювання, впровадження інновацій, оновлення асортименту продукції, реагування бізнесу на нові тенденції в технології, техніці, організації виробництва, організаційній структурі управління та інших складових господарської діяльності.

В актах ревізії доцільно виділяти спеціальний розділ з контролю якості менеджменту за ієрархічними рівнями. Якщо для середнього рівня управління існуючі облікові системи дають певний обсяг інформації (хоча і недостатній в умовах ринку з точки зору можливостей отримання будь якого обсягу даних для роботи менеджерів за допомогою комп'ютерної техніки), то для нижчого, де відбуваються основні події господарської діяльності, а також для вищого рівня управління, який зобов'язаний передбачати події на тривалу перспективу, як правило, інформації недостатньо або взагалі немає. То про який контроль можна говорити за такої ситуації? Зрозуміло, що інформація фінансового обліку обмежена і стосується історії господарювання, нехай і найновішої (за минулий квартал), тому контроль (внутрішній і зовнішній) вимушено зводиться до його ретроспективного виду, що порушує логіку управління, для якого важливо знати не стільки події минулого, скільки тих, що відбуваються в реальному часі і прогнозуються на майбутнє. Превентивний контроль менеджерів нижчого рівня за відсутності нормативного методу обліку витрат практично неможливо здійснити, а перспективний аналіз діяльності підприємства позбавлений всякого сенсу, оскільки стратегічний облік поки що в Україні $€$ екзотичними видами інформаційних підсистем, які впроваджені на досить обмеженій кількості підприємств, як правило, великих.

Отже, головною умовою формування науки про контроль стає вирішення проблеми створення розвинутої інформаційної системи на новій теоретичній базі, яка здатна давати повний обсяг інформації у просторовому та часовому вимірах, що дозволяє всебічно характеризувати 
господарську діяльність, яка відбулася у минулому періоді (фінансовий облік), відбувається в реальному часі (управлінський облік) та діяльність, що очікується у перспективі на основі стратегічного обліку.

Контроль спрямовують на фрінансову й бюджетну сферу, операції з виконання робіт у технологічному процесі, взаємовідносини підприємства з дебіторами і кредиторами, ефективність використання ресурсів і процесів. Інформаційні ресурси щодо цих видів робіт формує система обліку, яка включає три підсистеми: фінансового, управлінського і стратегічного обліку.

Система контролю повинна впливати на систему обліку в такому напрямі, щоб можна було одержати інформацію про такі об'єкти:

- технологію виробництва (виявлення вузьких місць, фракторів впливу, відхилення, причини, наслідки, заходи попередження);

- якість праці персоналу (продуктивність, використання робочого часу, проблеми зайнятості, оплата праці, стимулювання);

- реалізацію завдань, етапів, напрямів стратегічних програм, бюджетів (план, факт, відхилення, причини, фактори впливу, проблеми різного характеру);

- обсяг залучених фактори виробництва та процкс їх раціональне використання;

- ефективність окремих процесів (постачання, виробництво, збут, інвестування);

- дотримання законодавства та внутрішніх регламентів (наказів, інструкцій, розпоряджень, що стосуються господарської та фінансової діяльності);

- рівень дотримання параметрів фінансової та господарської діяльності (норми, нормативи, звіти, економічні показники, динаміка показників).

Якість контролю залежить від інформаційних ресурсів, які отримують за допомогою інформаційних технологій за наперед визначеним обсягом первинних даних та їх трансформації в інформаційні ресурси. При цьому з невеликого обсягу вхідних даних можна отримати безмежний обсяг вихідної інформації. Наприклад, за допомогою сканера і штрих кодів на товари, можна отримати дані в такому розрізі:

- назва проданого товару (кількість, сума, походження товару, сорт та інші дані);

- час продажу (сума та кількість продажу за годину, до 12 години, до 16 години);

- відділ (секція, група товарів, сума, кількість продажу);

- найбільші платежі за день (кількість покупців, сума, назва товарів);

- в який час і в яких відділах найбільша виручка та багато іншої інформації, яка дає уяву про підприємство та його роботу в реальному часі.

Нами наведено лише незначну кількість показників, які можна отримати для аналізу й контролю продажу навіть у дрібних роздрібних магазинах, не говорячи про великі, що було неможливим раніше і що не роблять до цього часу бухгалтери, хоча $€$ технічна можливість організувати облік будь-чого в реальному часі, тому цінну інформацію менеджери не використовують на практиці для контролю внутрішнього і зовнішнього середовища і пошуку резервів нарощування обсягу продажу.

Архаїчність системи обліку, яка зберігає свої риси до цього часу, неминуче тягне за собою примітивні форми, види і методи контролю, що позначається негативно на результатах діяльності і ефективності роботи бухгалтерського і контрольного апарату. Відсталість систем обліку й контролю від запитів системи управління обумовлено соціологією знання, яка завжди відстає у своєму розвитку від потреб суспільства [17].

Особливу роль в управлінні і контролі діяльності підприємства відіграє людський капітал, який не знаходить відображення в системах обліку й контролю та в розрахунках ефективності роботи. Це стосується соціальної інформації (кадри, освітній та кваліфікаційний склад, навчання кадрів і підвищення кваліфікації, оплата праці, диференціація оплати між категоріями працюючих, мотивація та стимулювання праці, продуктивність праці, конфлікти, витрати робочого часу на випуск продукції, соціальні пільги, житлові умови, соціальний пакет, тендерна політика та інші) [18, 
C. 182-189].

Розширення інформаційних ресурсів не $є$ самоціллю, а засобом досягнення творчого елементу в роботі менеджерів, зменшення рутинної частини роботи на користь творчості, що означає підвищення рівня інтелектуалізації персоналу та обгрунтованості рішень працівниками управління.

Суспільство в подальшому все в більшій мірі буде орієнтуватися на інтелектуалізацію праці, особливо управлінського апарату, сферу наукових досліджень, формування знань підприємства та кожного працівника з тим, щоб перейти до найновішого технологічного укладу, що формується на основі нано-, фемто- і пікотехнологій (масштаб мікросвіту відповідно 10-9, 10-12, 10-15 метра).

На жаль, в Україні частка технологічного укладу з використанням високих технологій надзвичайно низька, що $є$ наслідком низького рівня підготовки сучасних фахівців $з$ позицій майбутніх вимог до персоналу в постіндустріальному суспільстві.

Тенденції світової економіки свідчать про те, що підприємство, як частина економіки країни, розвиваються у напрямі від простих структур організації та функціонування до складних і надскладних, а тому контроль не повинен зациклюватися лише на перевірці тих подій, що зафріксовані в первинних документах підприємства, а зосереджуватися на відстеженні подій, тенденцій, закономірностей розвитку економіки на конкуруючих підприємствах, галузях, окремих кластерах, регіонах, державі в цілому. Моніторинг та контроль технологічних зрушень, подолання розривів між досягненнями науки і недосконалою практикою підприємств дозволяє отримати великий обсяг інформації з допомогою сучасних інфрормаційних технологій.

Обліковій та контрольній службам потрібно було років 30 тому перейти до сучасних методів збору даних і обробки інформації зробивши стрибок від відсталих технологій, які відбивають рівень розвитку економіки феодалізму, до нових, дійсно заснованих на можливостях сучасної науки й техніки, що дасть можливість економити ресурси, давати споживачу продукцію, яка відповідає світовому рівню, отримувати конкурентні переваги на внутрішньому і зовнішньому ринках, увійти в число розвинутих країн світу.

Без контролю, як засобу отримання інформації про стан об'єкту (не важливо чи це речі, явища і процеси) у відповідності до його бажаного стану та виявлення змін і факторів впливу на ці об'єкти, неможливе існування практичної діяльності в її цілеспрямованому розвитку та бажаних змінах на перспективу [18, с. 75-120].

Науку про контроль потрібно розуміти як механізм впливу на господарську діяльність суспільства в напрямі ії удосконалення на основі врахування економічних законів, тенденцій розвитку бізнесу та задоволення потреб населення при мінімальних витратах і максимальній економічній та соціальній віддачі.

На сучасному етапі розвитку суспільства контроль $€$ мистецтвом, оскільки його наукова концепція знаходиться в стадії формування, а науковий апарат являє собою компендіум поглядів окремих авторів на ті чи інші практичні дії з контрольної діяльності.

\section{Висновки і перспективи.}

Для переходу контролю із стадії мистецтва, в якій він перебуває зараз, до стадії науки, необхідні певні умов:

- посилення філософських основ у формуванні теорії контролю, як бази пізнання сутності економічного буття та мислення людини. Потрібно трактувати явища і процеси не як окремі сутності, а в їх діалектичній єдності. Буття означає загальну категорію для позначення реально існуючого світу та його складових, а мислення - здатність відображати цю реальність у свідомості людини. У той же час мислення людини породжується буттям. Мислення та буття, як здатність відображення об'єктів реального світу, взаємопов'язані практикою, що означає реальне перетворення дійсності на основі певного ідеального (мисленнєвого) плану в позитивний результат такого перетворення, що є свідченням істинності мислення, яке складає зміст цього ідеального 
плану. Мислення, пізнання, свідомість та ідеальне виступають як елементи більш широкого цілого, яке називають наукою, що обслуговує практичну матеріальну діяльність [17, с. 106].

- наука і практика активно взаємодіють виступаючи відносно окремими складовими буття, які мають свої власні структури. Теорія (наука) дає ідеальне уявлення про функціонування системи контролю, що виконує корисні функції у практичній діяльності людей, а практика на емпіричному рівні узагальнює досвід діяльності надаючи інформацію для уточнення й розвитку теорії. Контроль, як практична діяльність, існує з прадавніх часів, але теорія до цього часу не розроблена. Щоб перетворити практику контролю (мистецтво) в науку, потрібно зайнятися теорією;

- наука про контроль являє собою ідеальний план пізнання реальності (контрольного середовища), призначеного для організації раціональної практичної роботи на основі пізнавальних норм і засобів, що позитивно впливає на результати фінансової і господарської діяльності бізнесу. На певному етапі розвитку практики формується наука, яка відокремлюється від безпосередньої практичної діяльності та отримує статус відносно незалежного і самостійного виду духовного виробництва. Наука про контроль є системою, що включає такі елементи, як мета, засоби пізнання середовища, закономірності формування знань про предмет, об'єкти, суб'єкти, методи та інструменти дослідження поведінки об'єктів контролю, умови, які визначають структуру науки тощо. Потрібно формувати теорію науки не лише за дисциплінарним, а й за проблемним принципом, що вимагає синтезування знань різних галузей науки;

- в теорії контролю потрібно розвивати принцип логічної аргументації, як однієї з норм наукового мислення. Аргументація теорії науки постійно змінюється внаслідок ускладнення господарської діяльності, розвитку науково-технічного прогресу, зрілості самої науки та розвитку її окремих елементів. Не може бути теорії контролю застиглої у часі. По мірі наростання в ній нових елементів та відмирання старих формується нова парадигма, адекватна новим реаліям економічної політики;

- наука, як форма теоретичної пізнання, з'являється тоді, коли знання у вигляді практично зафіксованих закономірностей, алгоритмів роботи, схем, методів не просто закріплюють у вигляді ідеальних планів практичної діяльності (правила, інструкції, технологія виконання дій), а стають предметом спеціалізованої діяльності (виділення структурних відділів контролю на регулярній основі). Наука не просто оперує поняттями (абстракції, закони, зв'язки, відношення між ними), а безпосередньо впливає на практику. Спеціалізована діяльність пов'язується з фрормуванням і розвитком понятійного апарату, який відрізняється від понять звичайного побутового рівня мислення;

- наука пов'язана з виробництвом «ідей», що вимагає активного пошуку і виділення спеціальних механізмів усвідомлення, нормування, прогнозування та управління дослідженнями в предметній галузі. Теоретична свідомість застосовує спеціальні словесно - дискурсивні процедури і виробляє загальноприйняті аргументовані «значення», які протилежні аморфним уявленням і «поглядам» буденної свідомості. Для перетворення сучасної парадигми контролю 3 «рецептурного» на «системно - теоретичне» знання, потрібні не міркування окремих авторів щодо включення в теорію тих чи інших окремих елементів науки (часто без будь - якої аргументації), а розроблені ними певні теоретичні моделі з поясненням їх функціонування;

- теорія ґрунтується на принципах доведення та конструктивізму, які сприяють виявленню та оцінці різних альтернатив, обґрунтувань, можливостей руху думки та вибору найбільш доцільних та перспективних з них. Наука може розвиватися на законах діалектики (рух, зміни, протиріччя, переходи, перетворення, прогрес, взаємодія елементів, боротьба старого і нового, гнучкість, адаптивність тощо), застосування категорійного апарату (форма і зміст, аналіз та синтез, індукція і дедукція, явище і сутність, кількість і міра та інші), ідей, гіпотез, концепцій, принципів, методології, методики, процедур, алгоритмів, правил та іншого інструментарію, що дозволяє розробляти теоретичні пізнавальні норми і заходи, які стають актуальними для практики;

- наука оперує «ідеальними» об'єктами, які не зводяться до звичайних «земних». Ідеальні 
об'єкти створюються мисленням, абстракціями, вони опосередковані певними передумовами філософсько-методологічного характеру. Разом з тим теорія асимілює та осмислює в науковій картині бачення предмету науки емпіричний матеріал, який служить механізмом зворотного зв'язку теорії 3 практикою і практики 3 теорією. Саме такий принцип розвитку науки повинні використовувати дослідники проблем контролю;

- теорія контролю повинна враховувати інституційну роль науки, яка полягає в розширенні достовірного знання на основі підтверджених і логічно узгоджених тверджень, що виражають існування певних регулярностей у суспільному житті. У якості компонентів етосу (сукупності етичних орієнтирів) сучасної науки звичайно беруть чотири набори інституційних імперативів: універсалізм, всезагальність, незаінтересованість та організований скептицизм . До цих імперативів додають ще оригінальність, інтелектуальну скромність, незалежність, емоційність, нейтральність та неупередженість;

- розвинута теорія контролю повинна базуватися на сучасних принципах комплексності досліджень на основі історичного, соціологічного, економічного, екологічного, етичного, системного, структурного, кібернетичного та інших підходів і використання досягнень інших наук (принцип міжпредметних зв'язків).

- теорія контролю повинна розвиватися разом з новою теорією обліку, як сервісною системою, що генерує різноманітну інформацію щодо внутрішнього і зовнішнього середовищ бізнесу і дає можливість контролювати явища і поцеси фінансової та господарської діяльності у просторовому і часовому вимірах.

Обговорення проблем теорії контролю не тільки назріло в нашій країні, а й перезріло, оскільки в економічній сфрері відбуваються деструктивні процеси - крадіжки бюджетних коштів у непомірно великих розмрах, незаконне привласнення майна, рейдерство, хаос у ціноутворенні, необірунтованість тарифів тощо, які $€$ наслідком нікчемності існуючої системи контролю, що загрожує економічній безпеці та існуванню держави.

\section{Список використаних джерел}

1. Кочерин Е.А. Контроль в системе управления социалистическим производством. Вопросы теории и практики. Москва : Экономика, 1974. 216 с. $166 \mathrm{c}$.

2. Видяпин В.Г., Барсукова И.В. Теория финансово-хозяйственного контроля. Москва : МИНХ, 1988.

3. Білуха М.Т. Теорія фінансово-господарського контролю і аудиту. Київ : ПП «Влад і Влада», 1996. 320 c.

4. Шевчук В.О. Контроль господарських систем в суспільстві 3 перехідною економікою (проблеми теорії, організації, методології) : монографія. Київ : КДТЕУ, 1998. 371 с.

5. Ярошенко С.П., Пінькас Г.І., Кобичева О.С. Теоретичні і методологічні основи контролю : монографія. Суми : ВТД «Університетська книга», 2007. 251 с.

6. Виговська Н.Г. Господарський контроль в Україні: теорія, методологія, організація : монографія. Житомир : ЖДТУ, 2008. 532 c.

7. Редченко К.І. Контроль і аудит на стратегічному рівні управління підприємством : монографія. Львів : ЛКА, 2011. $360 \mathrm{c}$. 2011. $140 \mathrm{c}$.

8. Пушкар М. С. Теорія пізнання у розвитку науки про контроль: монографія. Тернопіль : Карт-бланш,

9. Старіш О. Г. Системологія. Київ : ЦНЛ, 2005. С. 50-51.

10. Малкей М. Наука и социология знания: пер. с англ. А.Л. Великовича, послесл. к.ф.н. В.Г. Юдина. Москва : Прогресс, 1983. 253с.

11. Кун Т. Структура научных революций ; пер. с англ. И.З. Налетова. Москва : АСТ, 2009. 310 с.

12. Могилевский В.Д. Методология систем: вербальный поход / Отдел. экон. РАН; науч. ред. совет изд-ва «Экономика». Москва : ОАО Издательство «Экономика», 1999. С. 19. (системные проблемы России).

13. Рач В., Расошанська О., Медведєва О. Побудова термінологічної системи організації наукового. Пізнання. Науковий світ. 2011. № 4. С. 13-16

14. Философский словарь. Под. ред. М.М. Розенталя. изд. 3-е. Москва : Политиздат, 1972. 
15. Орбан-Лембрик Л.Е. Психологія управління. Київ : Академвидав, 2003. 508 с.

16. Фалмер Роберт М. Энциклопедия современного управления в пяти томах. Том IV. Контроль как функция управления ; пер. с анг. ; общая ред. к.э.н. Х.А. Бекова, Н.П. Володиной. Москва : ВИПКэнерго, 1992.

17. Швырев В.С. Научное знание как деятельность. Москва : Политиздат, 1984. 232 с.

18. Пушкар М.С. Анатомія бізнесу в інформаційному полі підприємства: монографія. Тернопіль : Картбланш, 2017. 212 c.

19. Пушкар М.С., Чумаченко М.Г. Ідеальна система облвку: концепція, архітектура, інформація: монографія. Тернопіль : Карт-бланш, 2011. 336 с.

Статтю отримано: 20.10.2017 / Рецензування 25.11.2017 / Прийнято до друку: 14.12.2017

\author{
Mykhailo Pushkar \\ Dr.Sc. (in Economics), Professor \\ Department of audit, control and analysis \\ Ternopil National Economic University \\ Ternopil, Ukraine \\ E-mail: mspushkar@gmail.com
}

\title{
SCIENTIFIC APPARATUS FOR CONTROL THEORY DEVELOPMENT
}

\begin{abstract}
Abstact
Introduction. The current control can't effectively influence the practical organization of macro and micro levels of economic management due to significant gap between the theory and practical needs. The lack of a well-developed theory generates chaos in control activities in the country and destructive processes in the economic sectors of the country and business. Lax control provokes corruption and irresponsibility of the personnel for the implication of decisions.

Methods. Research methods of modern control theory are based on general, economic and special learning techniques of trends and patterns of science study development, philosophy, history, sociology, methodology, achievements in different sciences that can be adopted for intellectualization of control process. Cognition is impossible without dialectical thinking that takes into consideration the specific nature of control employees work and its disclosure in the theory of control. The performance of control functions is quite problematic without scientific concepts of controlling staff training, shape of their worldview and creation of effective system of control.

Results. The results of the research study on the theory of control demonstrate extremely low intellectual level of scientific generalization of control process that is aimed to elevate to higher standards. Imperfections in accounting system provide little information for the control and make it ineffective. Control is limited by the set of economic indicators that generates accounting. That is why it only determines the validity of operation instead of studying the effectiveness of management and control processes.

Discussion. The author suggests that the control development perspective considers the creation of such a theory, which is based on the principles of learning theory that provides a completely new approach to perception of such categories as control, structure of its system, functions, tasks, goals, the methodology and other items.

Keywords. control, system of accounting, accounting, science, theory of knowledge, management, development perspectives.

\section{References}

1. Kocheryn, E.A. (1974). Kontrol' v sisteme upravlenija socialisticheskim proizvodstvom Voprosy teorii $i$ praktiki [Control in the system of management of socialist production. Questions of theory and practice]. Moskow : Jekonomyka. [in Rus.]

2. Vydiapyn, V.H., \& Barsukova, Y.V. (1988). Teoryia fynansovo-khoziaistvennoho kontrolia [Theory of financial and economic control]. Moskow : MYNKh. [in Rus.]

3. Bilukha, M.T. (1996). Teoriia finansovo-hospodarskoho kontroliu $i$ audytu [Theory of financial and economic control and audit]. Kyiv : PP «Vlad i Vlada». [in Ukranian]

4. Shevchuk, V.O. (1998). Kontrol hospodarskykh system v suspilstvi z perekhidnoiu ekonomikoiu (problemy teorii, orhanizatsii, metodolohii): monohrafiia [Control of economic systems in a society with a transitional economy (problems of theory, organization, methodology): monograph]. Kyiv : KDTEU. [in Ukranian]

5. Yaroshenko, S.P., Pinkas, H.I., \& Kobycheva, O.S. (2007). Teoretychni i metodolohichni osnovy kontroliu :
\end{abstract}


monohrafiia [Theoretical and methodological basis of control: monograph]. Sumy : VTD «Universytetska knyha».[in Ukranian]

6. Vyhovska, N.H. (2008). Hospodarskyi kontrol v Ukraini: teoriia, metodolohiia, orhanizatsiia : monohrafiia [Economic control in Ukraine: theory, methodology, organization: monograph]. Zhytomyr : ZhDTU. [in Ukranian]

7. Redchenko, K.I. (2011). Kontrol $i$ audyt na stratehichnomu rivni upravlinnia pidpryiemstvom : monohrafiia [Control and audit at the strategic level of enterprise management: monograph]. Lviv : LKA. [in Ukranian]

8. Pushkar, M. S. (2011). Teoriia piznannia u rozvytku nauky pro kontrol: monohrafiia [Theory of knowledge in the development of the science of control: monograph]. Ternopil : Kart-blansh. [in Ukranian]

9. Starish, O. H. (2005). Systemolohiia [Systemology]. Kyiv : TsNL. [in Rus.]

10. Malkei, M. (1983). Nauka y sotsyolohyia znanyia: per. s anhl. A.L. Velykovycha [Science and the sociology of knowledge (A.L. Velykovych, Transl.)]. Moskow : Prohress. [in Rus.]

11. Kun, T. (2009). Struktura nauchnyh revoljucij perev. Naletov Y.Z. [Structure of scientific revolutions (O.F. Naletova, Transl)]. Moskow : AST. [in Rus.]

12. Mohylevskyi, V.D. (1999). Metodologija sistem: verbal'nyj podhod [Methodology of systems: a verbal approach]. Moskow : Jekonomika. [in Rus.]

13. Rach, V., Rasoshanska, O., \& Medvedieva, O. (2011). Pobudova terminolohichnoi systemy orhanizatsii naukovoho piznannia [The construction of the terminological system of organization of scientific knowledge]. Naukovyi svit, 4, 13-16. [in Ukranian]

14. Rozental, M.M. (Ed.) (1972). Fylosofskyi slovar. yzd. 3-e [Philosophical dictionary]. Moskow : Polytyzdat, 1972. [in Rus.]

15. Orban-Lembryk, L.E. (2003). Psykholohiia upravlinnia [Psychology of management]. Kyiv : Akademvydav. [in Ukranian]

16. Falmer, Robert M. (1992). Kontrol kak funktsyia upravlenyia. This is a chapter [Control as a function of management. In Bekov, Kh.A., \& Volodyna, N.P. (Eds.), Encyclopedia of modern management in five volumes]. Moskow : VIPKjenergo. [in Rus.]

17. Shvyrev, V.S. (1984). Nauchnoe znanye kak deiatelnost [Scientific knowledge as an activity]. Moskow : Polytyzdat. [in Rus.]

18. Pushkar, M.S. (2007). Anatomiia biznesu v informatsiinomu poli pidpryiemstva: monohrafiia [Anatomy of business in the information field of the enterprise: monograph]. Ternopil : Kart-blansh. [in Ukranian]

19. Pushkar, M.S., \& Chumachenko, M.H. (2011). Idealna systema oblvku: kontseptsiia, arkhitektura, informatsiia: monohrafiia [Ideal system of the field: concept, architecture, information: monograph]. Ternopil : Kartblansh. [in Ukranian]

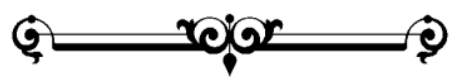

